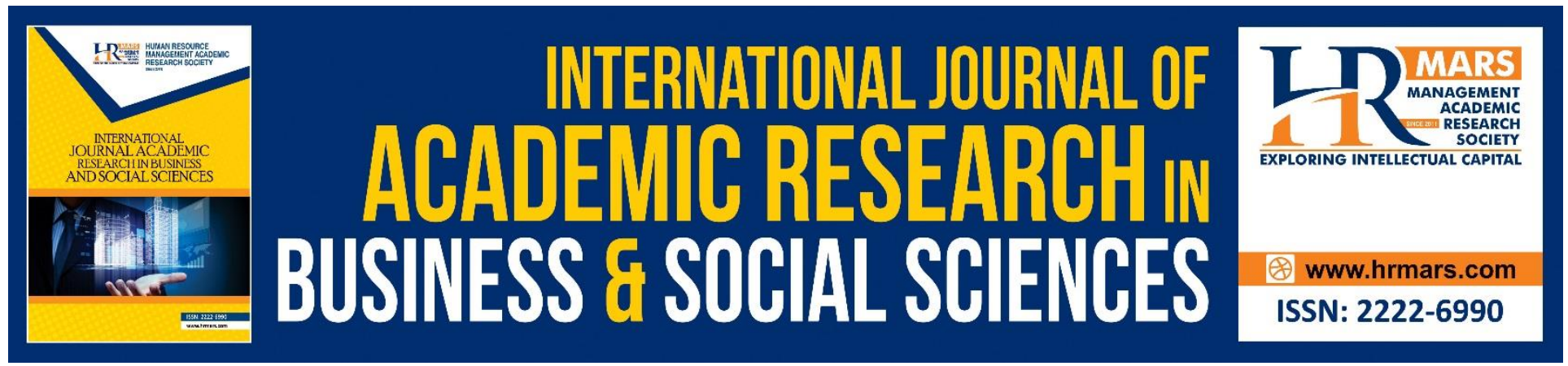

\title{
Indicators for Cooperative Performance Measurement
}

\author{
Zelhuda Shamsuddin, Suraya Mahmood, Puspa Liza Ghazali, \\ Fauzilah Salleh, Farah Amalina Md Nawi
}

To Link this Article: http://dx.doi.org/10.6007/IJARBSS/v8-i12/5056

DOI: $10.6007 /$ IJARBSS/v8-i12/5056

Received: 07 Oct 2018, Revised: 21 Nov 2018, Accepted: 24 Dec 2018

Published Online: 29 Dec 2018

In-Text Citation: (Shamsuddin, Mahmood, Ghazali, Salleh, \& Nawi, 2018)

To Cite this Article: Shamsuddin, Z., Mahmood, S., Ghazali, P. L., Salleh, F., \& Nawi, F. A. M. (2018). Indicators for Cooperative Performance Measurement. International Journal of Academic Research in Business and Social Sciences, 8(12), 577-585.

Copyright: (C) 2018 The Author(s)

Published by Human Resource Management Academic Research Society (www.hrmars.com)

This article is published under the Creative Commons Attribution (CC BY 4.0) license. Anyone may reproduce, distribute, translate and create derivative works of this article (for both commercial and non-commercial purposes), subject to full attribution to the original publication and authors. The full terms of this license may be seen at: http://creativecommons.org/licences/by/4.0/legalcode

Vol. 8, No. 12, 2018, Pg. 577 - 585

http://hrmars.com/index.php/pages/detail/IJARBSS

JOURNAL HOMEPAGE

Full Terms \& Conditions of access and use can be found at http://hrmars.com/index.php/pages/detail/publication-ethics 


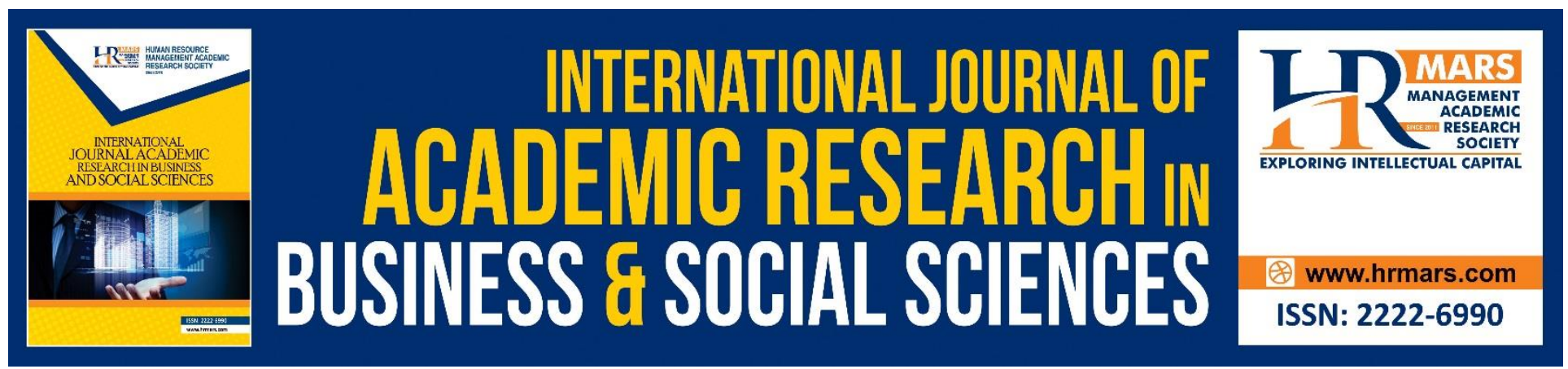

\title{
Indicators for Cooperative Performance Measurement
}

\author{
Zelhuda Shamsuddin ${ }^{1}$, Suraya Mahmood ${ }^{1 *}$, Puspa Liza Ghazali ${ }^{1}$, \\ Fauzilah Salleh ${ }^{1}$, Farah Amalina Md Nawi ${ }^{1}$ \\ ${ }^{1}$ Faculty of Economics and Science Management, Universiti Sultan Zainal Abidin, 21030 Kuala \\ Terengganu \\ *Email of Corresponding Author: surayamahmood@unisza.edu.my
}

\begin{abstract}
Cooperative enterprises have been recognized as a democratic entity organization. The financial statement is practically prepared for internal users (cooperative members) and for external users (The Cooperative Commission Malaysia (SKM)). The financial statement is a map to understand and measure the financial health of a cooperative. Financial ratio analysis has received the attention in determining detailed coverage of the cooperative liquidity, resources and operations. Report prepared from financial ratio analysis is extensively accepted whether it is a large or small company. This paper indicate financial and non-financial indicators that most importantly reflect business and can be used to examine the performance of cooperatives, most importantly to indicate which financial ratios that reflect business and financial position of cooperatives. Given the recent rapidly increased number of cooperative established with increased number of cooperative members and expectation of performance stability in Malaysia, it becomes a relevant subject matter to conduct this study.
\end{abstract}

Keywords: Co-operative, Financial Performance, Financial Ratio

\section{Introduction}

Cooperative movement in Malaysia has grown rapidly from 1922. In 2002, Malaysian government has introduced the first cooperative policy to maps the directions of cooperative firm in Malaysia known as National Cooperative Policy 2010. The main aim of the policy is to encourage cooperative movement actively in accordance with the national growth. This policy also introduced supportive government institution namely Cooperative Commission Malaysia (SKM) that provides financial support, business development, legislative update, and regulatory control under one Ministry. This policy further recognises that cooperative also plays an important role in socio-economic development, which concern for the community. To date, under the $10^{\text {th }}$ National Plan, National Cooperative Policy will be continuously implemented for ten years (2011-2020), consists of three phases which are short-term phase from January 2011 to December 2012, intermediate phase from January 2011 to December 2015, and long-term phase from January 2016 to December 2020. The 
INTERNATIONAL JOURNAL OF ACADEMIC RESEARCH IN BUSINESS AND SOCIAL SCIENCES Vol. 8, No. 12, Dec, 2018, E-ISSN: 2222-6990 @ 2018 HRMARS

cooperative movement continue to grow to 13428 cooperative in 2016 compared to only 9 cooperative in 1922. Malaysian cooperatives include variety of clusters which includes consumer, agriculture, housing, transportation, industrial, and service. Membership of cooperative was opened to government servants, statutory body, private sector servants, pensioners, fishermen, professional and others. All cooperative in Malaysia are subject to the Cooperative Act 1993 (No. 502 of 1993) on 4 February 1993. However, a few amendments have been made in 2007, to offer more opportunities for public to establish cooperative with a minimum of fifty people.

Performance measurement in cooperatives has mostly remain to its financial dimension and focus on financial stability. This study contributes to the literatures by studying financial indicators that referred to 'objectives and goals measures' and 'efficiency of using available resources'. With regard to cooperatives purpose of performance measurement is to provide financial decisions to manager and improve performance. Another purpose includes reporting their correct use of resources especially to cooperatives members which is the main funder of cooperatives. However, demonstrating performance measures according to the objectives of the firm is seen as an important key for success (Mulgan, 2010). Therefore, measurement performance of cooperative in using financial ratios or non-financial indicators must be developed to determine the best measures that serve its purpose and objectives.

In respond to the increasing number of cooperatives and its contribution in the economy, cooperative must be stable in financial performance for long-term survival. In relation to Malaysia cooperative performance, the lack of research on cooperative financial performance measure is due to the limitation of data access to public. Taken together, there is a need for an in-depth research to better understand the relevant financial ratios and non-financial indicator that can contribute to cooperatives financial performance, especially in Malaysia. Since the main objectives of cooperative is to fulfil the members' interest and welfare, this paper contributes to the body of knowledge as there is a lacking in performance measurement which is reflective to members' interest and welfare.

This paper is organized as follows: the next section (Section 2) provides literature review; Section 3 discusses the relevant financial indicators developed and followed by a conclusion.

\section{Financial Ratios and Performance}

The formation of cooperative firm is purposely to provide the need of members with continuing focusing on ensuring benefits to member and retains a sufficient profit to own operations as an enterprise. Therefore, cooperatives are business enterprise that owned, controlled, and aimed for the benefits of their members, provide different objectives than investor-owned company (shareholder value-oriented firms), as profit maximizes. The cooperatives aim to provide product or services to its members and the surpluses are distributed according to capital contributed by patronage and members as shareholding (Soboh, et al., 2011). The investor-owned firm (IOF) objective is to maximize return from investment and distribute profit according to the investment. The IOF sources of capital are from the shares that publicly traded and external financing. Whereas, the main source of capital for cooperatives is from their members retained equity. As we have discuss above, the owners of IOF are interested in the return from their investment, contrary to the 
INTERNATIONAL JOURNAL OF ACADEMIC RESEARCH IN BUSINESS AND SOCIAL SCIENCES Vol. 8, No. 12, Dec, 2018, E-ISSN: 2222-6990 @ 2018 HRMARS

cooperatives owner, which are interested with the services and benefits provided by the cooperatives, such as a high price in their produces product or services.In order to attract members and sustainable dividend payment, cooperative needs to be compelling in their financial and operating performance.

A financial ratio has been used in evaluating the performance and financial condition of a firm. Financial ratios offer an indication of the firm position in the dimensions of profitability, liquidity, solvency and efficiency. Financial ratios approach allows analysis particularly, by assessing the financial health and potential of insolvency. Furthermore, ratios analysis allows an assessment of how various line items in a firm's standard financial statements relate to one another. Ratio analysis has received the most attention in determining how performance of one firm relates to the performance of either a group of peers or the entire industry. Early researchers Pinches et al., (1973) have attempt an empirically based to reduce set of financial ratios to represent seven ratios - return of investment, financial leverage, capital turnover, short-term liquidity, cash position, inventory turnover, and receivables turnover. These seven financial ratios occurred in each year examined, accounting for a consistency high amount of the variance and relatively stable for a long-term.

Similar study of reducing set of financial ratios using principles component analysis of 39 ratios of 1053 firms in 1977 has been done by Chen and Shimerda, (1981). The statistical tool used to summarize inter-relationships and group variables into a few factors that retain a maximum of information contained in the variable set. An example from the analysis: A ratio of Earning before interest and taxes/Sales and Net Income/Net Worth are significantly correlated and classified as ratios exhibiting return on investment activities. Their studies have demonstrates the importance to select a ratios that represent a factor that offer most of the common information retain in the factor.

Both empirical and analytical evidences found that financial ratios can be used to predict financial distress (Altman, 1968), to determine whether bad or potential performing firms (Kumar and Ravi, 2007), bankruptcy prediction using unique set of financial characteristic or different set of prediction model (Holsapple and Wu, 2011; Olson, et al., 2012), detecting fraudulent financial reporting in listed companies (Zainudin \& Hashim, 2016).

Likewise, a number of previous research used financial ratios to determine the financial performance of cooperative. Performance of cooperative is measured in two main categories: the first category consist of profitability and efficiency ratios that show the ability and the efficiency of equity capital to generate return. The second category consists of capital financing ratios to show the ability of the firms to pay debt and how cooperative finance its equity (Gengzoglanis, 1997; Lerman and Parliament, 1990; Harris and Fulton, 1996; McKee, 2008; Soboh, 2004; Soboh et al., 2011). Furthermore, financial ratio analysis is useful to measure member benefits transmitted by the cooperative to members in the short-run (McKee, 2008). Case analysis of insurance cooperative in North American revealed that the primary key performance index should include financial and nonfinancial indicators. Financial indicators consist of financial ratios of return on equity, gross written premium, combined ratio, loss ratio, expense ratio, and claim development. Whist non-financial ratios consist of staff profile, community investment, members and environment (Beaubien and 
INTERNATIONAL JOURNAL OF ACADEMIC RESEARCH IN BUSINESS AND SOCIAL SCIENCES Vol. 8, No. 12, Dec, 2018, E-ISSN: 2222-6990 @ 2018 HRMARS

Rixon, 2012). Noting that cooperative require a broader scope of performance than ordinary firms because of both financial strength and social requirement needs.

In relation to Malaysia cooperative performance, not many studies are done to evaluate the performance of cooperative. Prior studies in Malaysia cooperative tended to focus on research to several regions only and small numbers of sample with mixed findings on the performance measurement in the aspects of ratio analysis only. A study of cooperative performance is done by Hassan and Mat Noh (2005) that only focused to cooperative organization operates in state of Kedah and the performance evaluation are based on liquidity, leverage, and profitability ratios. A performance measurement of cooperative in Malaysia is also documented in studies that examine economic performance and member benefits performance (Kaur, 2006). A sample of 20 large cooperative and twenty small cooperative was selected to measure financial performance and member benefits. Overall findings indicate the financial performance that measure from the aspects of profitability and liquidity ratios varies between large and small cooperative.

Most of the cooperative performance in U.S and Europe is measured using regression analysis to compare the financial performance in terms of profitability, productivity, liquidity, leverage, and asset efficiency ratios. These findings are mixed regarding the financial performance of cooperative and IOFs and not take into account the members benefits or dividend in the performance evaluation.

This paper contributes to cooperative financial performance literature by conclude that performance measurement practices should covered all aspects related to members interest and welfare. The cooperative incorporate both democratic control and business functions in their social organization. These values and principles result an integrated expectation of financial performance and social objectives. Without appropriate measures, cooperative social development is deficient.

\section{Financial indicators and non-financial indicators in cooperative}

Financial information through financial reporting and financial analysis will reduce information asymmetries between cooperative members and managers. Cooperative members will accept a lower return in terms of dividends, members benefit and other benefits from cooperative because of the lower risk of the cooperative. Financial ratios provides significant information regarding financing activities, the operating cost, business stability and it depends on the information needs of the users. For examples, financial performance measures such as profitability ratios, coherently describes objectives of firms in a long run which reflect the aggregate view of purely financial performance. Financial indicators offer information regarding the financial status of firms and thus it helps the managers to make decision accordingly to improve the financial performance.

Non-financial indicators that reflect the cooperative business operations include staff profile, community investment, members and environment (Beaubien \& Rixon, 2012). Other indicators that can be measured, such as customer satisfaction, employ qualified employees, level of employees retention, shareholders satisfaction which is attributes to performance (Suklev \& Debarliev, 2012). 
INTERNATIONAL JOURNAL OF ACADEMIC RESEARCH IN BUSINESS AND SOCIAL SCIENCES

Vol. 8, No. 12, Dec, 2018, E-ISSN: 2222-6990 @ 2018 HRMARS

Table 1 lists and briefly defines the financial ratios most reported by cooperative researchers with are not exclusive in assessing cooperative performance (Gentzoglanis, 1997; Harris and Fulton, 1996; Schrader et al., 1985; Chen et al., 1985; Lerman and Parliament, 1991; Hardesty and Salgia, 2004; Notta and Vlachvei, 2007, Soboh et al., 2009; Kalogeras et al., 2013; Beaubien and Rixon, 2012).

Liquidity

Liquidity ratios indicate the ability of a business to pay its short term debt. The higher the liquidity ratio, the higher the margin of safety to meets its obligation. A study by Daniel et al. (2014), Zainudin and Hashim (2016) suggest low liquidity indicate that the company cannot meet their short term obligations and more likely for mangers to engage in fraudulent financial reporting. Liquidity ratio includes current ratio, quick ratio, working capital ratio, and cash ratio. In respect to cooperative, the current and quick ratios are most useful when analysing for comparison in time series and cross sectional analysis (Lerman and Parliament, 1990; Kaur 2006)

\section{Leverage}

Leverage ratios indicate the ability of a business to meets its short term and long term debt. A high debt may increase the risk of bankruptcy of a business. Debt must be used efficiently to produce a high return to business. In cooperative, the main source of capital is from the members. Thus, a cooperative source of capital is limited compared to listed companies which have an option to issue new ordinary shares to get more fund. Alternatively cooperative used debt as source of financing to operate its business, as such increasing the risk of financing to cooperative members. Previous research used total debt to total asset, long-term debt to total equity, total liability to total equity, equity to total asset in determining the debt level of cooperative (Soboh et al., 2009; Kaur, 2006; Lerman and Parliament, 1991)

\section{Asset utilization}

Asset utilization indicates the ability of a business to uses its asset such as account receivables, inventory to generate sales. The shorter the asset conversion period, the better used of its assets, means the ratio would be greater. The most frequent ratios used in cooperative researcher are total asset turnover, net fixed asset turnover and sales to total assets (Gentozoglanis, 1997; Kalogeras et al., 2005; Lerman and Parliament, 1991, Kalogeras et al., 2013).

\section{Profitability}

A firm's ability to generate income can be examined using a valuation technique of profitability. Business fundamental goal is to earn profit but cooperatives often have other objectives, such as to provide consistent dividends and member's benefit, to offer low prices of products to members, to offer training and education, and increase the well-being of members. A successful manager and cooperative Board Members can be evaluated through these additional objectives, thus maximise the objective of the cooperative members. The profitability ratios includes return on equity, return on assets, gross profit, net profit, and net income to net worth (Soboh et al., 2009; Kaur, 2006; Lerman and Parliament, 1991, Kalogeras et al., 2013). 
Table 1

Lists of Indicators

\section{Financial Indicators}

Liquidity ratios

Current ratio

Quick ratio

Cash ratio

\section{Leverage ratios}

Debt to total assets

Debt to equity

\section{Efficiency ratios}

Asset turnover

Net fixed asset turnover

Profitability ratios

Net profit margin

Return on equity

Return on total assets

Gross profit margin

Non-Financial Indicator

Staff profile

Community investment

Total members

Environment

\section{Formula}

Current asset $\div$ Current liabilities

(Current asset - Inventory) $\div$ Current liabilities

Cash + cash equivalent $\div$

Current liabilities

Total liabilities $\div$ Total assets

Total liabilities $\div$ Total equity

Sales $\div$ Total assets

Sales $\div$ Fixed assets

Net profits $\div$ Total assets

Net profits $\div$ Total equity

Net profits $\div$ Total assets

Sales - Cost of goods sold $\div$ Sales

Number of employees, employee turnover, employee engagement

Community investment, staff voluntary

Members

Energy used, renewable energy

\section{Indicator}

Indicator of short term solvency

Indicator of short term debt paying ability without relying on sale of inventory Indicator of short term debt ability relying on cash only

Indicator of asset claimed by outside interest

Indicator of cooperative financing for amount of equity provided by its members

Indicator of sales generated from cooperative assets

Indicator of the return of invested capital and managerial efficiency 
INTERNATIONAL JOURNAL OF ACADEMIC RESEARCH IN BUSINESS AND SOCIAL SCIENCES Vol. 8, No. 12, Dec, 2018, E-ISSN: 2222-6990 @ 2018 HRMARS

\section{Conclusion}

Cooperatives have been the most important part in the economy of Malaysia, especially in contributing to reduce level of poverty and participation of women in small region. Cooperative assessment requires a lot of quality and reliable information. The reliable information is from the financial report which consists of financial statement that gives information of cooperative business operation and governing. However, in Malaysia cases, it is argued that the detail information of financial data and financial report is hardly to get due to the main users of financial report of cooperative is only the Cooperative Board Members and SKM. So, in conducting an empirical research of Malaysia cooperative, it is encourage for researchers to consult SKM to ensure the measures of performance is accurate and reliable.

Most of the previous cooperative research used regression analysis to determine which financial indicators effect the performance or profit. It is suggested for future research to include a financial indicators that represent the members benefit, for example dividend rate, education or training to members, others members benefit, and other non-financial indicator into the analysis. Different ratios define different quality or business objectives. Despite of financial perspective, researchers can consider other cooperative objectives and subjective matter that reflect their business performance; for examples, its location or region, new product development, service or product quality, employee retention and background, members satisfaction and any business model reported by previous researchers.

\section{REFERENCES}

1. Altman, E. I. (1968). Financial ratios, discriminant analysis and the predication of corporate bankruptcy. The Journal of Finance, 23 (4), 589-609.

2. Beaubien, L. \& Rixon, D. (2012). Key Performance Indicators in Co-operatives: Direction and Principles. Journal of Co-operative Studies 45 (2): 5-15.Chen, K. H. and Shimerda, T. A. 1981. An Empirical Analysis of Useful Financial Ratios. Financial Management, 81 (10), 51-60.

3. Dalnial, H., Kamaluddin, A., Sanusi, Z. M. \& Khairuddin, K. S. (2014). Detecting fraudulent financial reporting through financial statement analysis. Journal of Accounting and Economics, 12 (1), 15-36

4. Delen, D., Kuzey, C., Uyar, A. (2013). Measuring firm performance using financial ratios: A decision tree approach. Expert System with Applications, 40, 3970-3983

5. Gentzoglanis, A. (1997). Economic and financial performance of cooperatives and investorowned firms: an empirical study. In J. Nilsson \& G. van Dijk (Eds.) Strategies and structures in the agro-food industries. Assen: Van Gorcum, 171-83.

6. Harris, A. and Fulton, M. (1996). Comparative financial performance analysis of Canadian cooperatives, investor-owned firms and industry norms. Occasional Paper Series, Saskatoon, Canada: Centre for the Study of Cooperatives.

7. Hassan, N. L. And Mat Noh, M. (2005). The Financial Performance of Co-operatives in Kedah State with Relation to Industry and Size. Working Papaer Series No. 14/2005

8. Holsapple, C. W. and Wu, J. (2011). An elusive antecedent of superior firm performance: The knowledge management factor. Decision Support System, 52 (1), 271-283. 
INTERNATIONAL JOURNAL OF ACADEMIC RESEARCH IN BUSINESS AND SOCIAL SCIENCES Vol. 8, No. 12, Dec, 2018, E-ISSN: 2222-6990 @ 2018 HRMARS

9. Kaur, I. (2006). Performance Measurement: An Evaluation of Co-operative Performance in Malaysia. Malaysian Journal of Cooperative Management, 1-17

10. Kalogeras, N., Baourakis, G., Zopounidis, C. and Van Dijk, G. (2005). Evaluating the financial performance of agri-food firms: A multicriteria decision-ad approach. Journal of Food Engineering, 70, 365-371.

11. Kumar, P. Ravi, and Vadlamani Ravi. (2007) Bankruptcy prediction in banks and firms via statistical and intelligent techniques-A review." European journal of operational research 180(1): 1-28.

12. Lerman, Z. and Parliament, C. (1990). Size and industry affects in the performance of agricultural co-cooperative. Agricultural Economics, 6, 15-29.

13. McKee, G. (2008). The Financial Performance of North Dakota Grain Marketing and Farm Supply Cooperatives. Journal of Cooperatives, 21, 15-34.

14. Mulgan, G, (2010). Measuring Social Value. Stanford Social Innovation Review, 8 (3): 38-43

15. Notta, O. and Vlachvei, A. (2007). Performance of Cooperatives and Investor-Owned Firms: The Case of the Greek Dairy Industry. In K. Karantininis and J. Nilsson, Vertical Markets and Cooperative Hierarchies - the Role of Cooperatives in the Agri-Food Industry. Dordrecht, The Netherlands: Springer Academic Publishers, 277-87.

16. Olson, D. L., Delen, D. and Meng, Y. (2012). Comparative analysis of data mining methods for bankruptcy prediction. Decision Support System, 52 (2), 464-473

17. Pinches, G. E., Mingo, K. A., and Caruthers, J. K. (1973). The Stability of Financial Patterns in Industrial Organizations. Journal of Finance, 389-396.

18. Soboh, R. A. M. E. (2004). The Financial Performance of Some Large Cooperatives in Europe, Comparison and Analysis. Business Economics and Management. Chania- Greece: Unpublished, M. Sc Thesis-International Center for Advanced Mediterranean Agronomic Studies.

19. Soboh, R. A. M. E., Lansink, A. O., Giesen, G and Van Dijk, G. (2009). Performance Measurement of the Agricultural Marketing Cooperatives: The Gap between Theory and Practice. Review of Agricultural Economics, 31, 446-469.

20. Soboh, R. A. M. E., Lansink, A. O., and Van Dijk, G. (2011). Distinguishing Dairy Cooperatives From Investor-Owned Firms in Europe Using Financial Indicators. Agribusiness, 27 (1), 34-46.

21. Zainudin, E. F., \& Hashim, H. A. (2016). Detecting fraudulent financial reporting using financial ratio. Journal of Financial Reporting and Accounting, 14(2), 266-278.

22. Kyriakopoulos, K., Meulenberg, M., \& Nilsson, J. (2004). The impact of cooperative structure and firm culture on market orientation and performance. Agribusiness, 20(4), 379-396.

23. Suklev, B. \& Debarliev, S. (2012). Strategic planning effectiveness comparing analysis of the Macedonian context. Economic and Business Review, 14(1), 63-93. 